(c) 2017, THE AUTHORS. Published by FASS and Elsevier Inc. on behalf of the American Dairy Science Association ${ }^{\circledR}$.

This is an open access article under the CC BY-NC-ND license (http://creativecommons.org/licenses/by-nc-nd/3.0/).

\title{
Associations between exposure to bovine herpesvirus 1 (BoHV-1) and milk production, reproductive performance, and mortality in Irish dairy herds
}

\author{
Ríona G. Sayers ${ }^{1}$ \\ Animal and Grassland Research and Innovation Centre, Teagasc, Moorepark, Fermoy, County Cork, Ireland
}

\begin{abstract}
As cost-benefit analyses are required to prioritize and promote disease control and eradication programs within a jurisdiction, national data relating to diseaserelated production losses are particularly useful. The objectives of the current study were to use Irish bovine herpesvirus 1 (BoHV-1) prevalence data in dairy herds, obtained by bulk milk sampling on 4 occasions over the 2009 lactation, to document associations between milk production, fertility performance, mortality, and BoHV1 herd status. Bulk milk $(\mathrm{n}=305)$ antibody ELISA was used to classify farms as positive or negative in terms of endemic BoHV-1. Cow-level (milk parameters only) and herd-level performance data were sourced from the Irish Cattle Breeding Federation. Ordinary linear and negative binomial regressions were used to investigate associations between milk, fertility, and mortality performance and herd-level BoHV-1 results (both categorical and continuous variables). Only slight effects on the rates of carryover cows, nonpregnant cows, and total deaths were highlighted with increasing ELISA sam$\mathrm{ple} /$ positive $(\%)$ values (incidence rate ratio $=1.001$ ) . Multiparous cows in herds BoHV-1 bulk milk antibody positive recorded a reduction in milk yield per cow per year of $250.9 \mathrm{~L}$ in the multivariable linear model. Milk fat and protein yields were also affected by herd BoHV-1 status, again highlighting sub-optimal milk production in BoHV-1 bulk milk-positive herds. The current study has highlighted an economical method of investigating losses due to endemic infection using repeated bulk milk sampling over a single lactation. These data can contribute to analyzing the cost-benefit of applying BoHV-1 control strategies both on farm and at a national level.
\end{abstract}

Key words: bovine herpesvirus 1, dairy herd, milk, fertility, mortality

\footnotetext{
Received February 29, 2016.

Accepted October 5, 2016.

${ }^{1}$ Corresponding author: Riona.Sayers@teagasc.ie
}

\section{INTRODUCTION}

Approximately $80 \%$ of the world's population live in developing countries, and the demand for meat and milk products in these countries is growing (Delgado, 2003; Narrod et al., 2012). In developed countries, consumption of these products is reducing, but the quality of product demanded is increasing (Narrod et al., 2011). To meet the demands of expanding markets and increased quality of product while remaining competitive, livestock producers will require improvements to the efficiency of animal production. Based on World Organisation for Animal Health (OIE) estimates that $20 \%$ of livestock production losses are directly related to animal disease (Vallat, 2008), epidemiological investigations outlining the specifics of disease-related production losses are necessary.

Planning and monitoring of disease eradication or control programs is most effective when based on knowledge of the prevalence of disease in a given population, the factors associated with occurrence of the disease, the methods available to control those factors, and finally the costs and benefits involved for a particular region (Thrushfield, 2005). As cost-benefit analyses are also required to both prioritize and promote disease control and eradication programs within a jurisdiction (Narrod et al., 2012), national data relating to diseaserelated production losses are particularly useful (Häsler et al., 2012).

Infectious bovine rhinotracheitis (IBR), caused by bovine herpesvirus 1 (BoHV-1), is a highly contagious viral disease of cattle (Engels and Ackermann, 1996; Muylkens et al., 2007; Raaperi et al., 2012a). It has a worldwide distribution and significant efforts have been made, particularly in European Union countries, to control and eradicate BoHV-1 (Ackermann and Engels, 2006). One of the many ways a disease can be characterized is by its economic consequences, and the primary motivation for eradication of BoHV-1 from livestock populations is its reported impact on the economic success of farming enterprises. Clinical signs of infection include abortion (Givens and Marley, 2008; Graham, 2013), suboptimal fertility, respiratory disease, reduced milk production, and increased mortality under experi- 
mental conditions (Bowen et al., 1985; Chiang et al., 1990; Miller et al., 1991) and natural field infection.

More specifically, Hage et al. (1998) described a significant decrease in milk production of $9.52 \mathrm{~kg}$ over a 14-d infectious period in BoHV-1 seronegative animals that became infected with the virus. Statham et al. (2015) recently reported a milk yield loss of $2.6 \mathrm{~kg} / \mathrm{d}$ in BoHV-1 seropositive compared with seronegative dairy cows. A Dutch modeling exercise quantified losses of $0.92 \mathrm{~kg}$ of milk per cow per day during a BoHV1 herd outbreak (van Schaik et al., 1999). Raaperi et al. (2012a) highlighted that herds with a BoHV-1 within-herd seroprevalence of between 1 and $49 \%$, have a higher risk of abortion (odds ratio $=7.3$ ). Moeller et al. (2013) reported that $2 \%$ of calves submitted for necropsy to the California Animal Health and Food Safety Laboratory (Tulare, CA) over a 6-yr period had lesions consistent with systemic BoHV-1 infection.

Although suboptimal performance due to infection with BoHV-1 has been reported widely, it should be noted that many studies have yielded contradictory results. Reproductive losses, for example, have not been found to be associated with exposure to BoHV-1 in beef herds (Waldner, 2005; Waldner and Kennedy, 2008) or in a dairy herd during a subclinical BoHV-1 infection (Hage et al., 1998). These contradictory findings are most likely due to the timing of infection, differences in the type of cattle herds being investigated (beef versus dairy), the jurisdiction where the study was completed, and livestock management systems operating in those jurisdictions. This stresses the importance of completing investigations specific to a particular region and livestock system.

Ireland is a net exporter of agricultural produce, with over $90 \%$ of dairy produce exported (Geary et al., 2010). Most Irish dairy farmers operate a pasturebased system, and Irish dairy cows graze pasture for approximately 10 mo of the year (Drennan et al., 2005). Limited data are available on the impact of BoHV-
1 in such a system, and it is important to examine whether the effect of BoHV-1 in Ireland is similar to that reported previously in more intensive livestock systems. Prevalence estimates of BoHV-1 exposure can be established using bulk milk analysis. A recent Irish study (Sayers et al., 2015) has outlined a bulk milk BoHV-1 seroprevalence in Irish dairy herds of $80 \%$. The objectives of the current study were to use these Irish prevalence data to document associations between milk production, fertility performance, mortality and viral status.

\section{MATERIALS AND METHODS}

\section{Herd Selection and Classification}

Selection of herds for this 2009 study was previously described, as was their BoHV-1 status (Sayers et al., 2015). Briefly, milk recording herds and members of HerdPlus (a breeding information tool; Irish Cattle Breeding Federation, Bandon, Co. Cork, Ireland) recorded in the Irish Cattle Breeding Federation (ICBF) database were used as the sample population and contained 3,500 members in 2009. Stratified proportional random sampling based on herd size and geographical location was used to select farmers for participation in the study. Of the 500 farmers invited to participate, 312 were eventually recruited on a voluntary and nonincentivized basis.

Over the 2009 lactation, 4 bulk milk samples (March 23, June 8, August 31, and November 2) were submitted by each study farm. Commercially available ELISA kits were used to test bulk milk samples for the presence of anti-BoHV-1 antibodies. Relevant kit performance data are outlined in Table 1, including manufacturerrecommended positive cut-off values used to classify herds as bulk milk antibody positive or negative.

Analyses were completed by commercial accredited laboratories: IBR lysate by National Milk Laborato-

Table 1. The ELISA kits used to test bulk milk samples for anti-bovine herpesvirus 1 (BoHV-1) antibodies in vaccinated and unvaccinated study herds

\begin{tabular}{|c|c|c|c|c|c|}
\hline $\begin{array}{l}\text { BoHV-1 herd } \\
\text { vaccination status }\end{array}$ & BoHV-1 antigen target & $\begin{array}{c}\text { Positive } \\
\text { cut-off value }\end{array}$ & $\begin{array}{l}\text { Sensitivity } \\
(\%)\end{array}$ & $\begin{array}{l}\text { Specificity } \\
(\%)\end{array}$ & $\begin{array}{c}\text { Within-herd } \\
\text { prevalence } \\
\text { detectable }(\%)\end{array}$ \\
\hline Unvaccinated & Ultrapurified IBR lysate $^{2}$ & $\begin{array}{c}\geq 25 \\
\% \mathrm{~S} / \mathrm{P}\end{array}$ & 100 & 99.6 & $10.0-15.0^{3}$ \\
\hline Vaccinated & $\operatorname{IBRgE}^{4}$ & $\begin{array}{l}\leq 0.8 \\
\mathrm{~S} / \mathrm{N} \text { ratio }\end{array}$ & $72.0-88.4$ & 100 & Not available \\
\hline
\end{tabular}

${ }^{1} \mathrm{~S} / \mathrm{P}$ (sample/positive) $=$ [optical density at $450 \mathrm{~nm}$ of sample $\left(\mathrm{OD}_{450}\right)-\mathrm{OD}_{450}$ of negative control $] /\left(\right.$ mean $\mathrm{OD}_{450}$ of positive control $-\mathrm{OD}_{450}$ of negative control) $\times 100 ; \mathrm{S} / \mathrm{N}$ (sample/negative) ratio $=($ sample mean - absorbance at $650 \mathrm{~nm}) /$ negative control mean.

${ }^{2}$ Institut Pourquier (Montpellier, France). IBR = infectious bovine rhinotracheitis.

${ }^{3}$ Wellenberg et al. (1998); Kramps et al. (2004).

${ }^{4}$ Idexx Laboratories (Westbrook, ME). 
ries Ltd. (Wolverhampton, UK), and IBRgE by Enfer Diagnostics Ltd. (Naas, Co. Kildare, Ireland). In addition, bulk milk data were available for each study herd from parallel studies regarding their disease status with regard to bovine viral diarrhea virus (BVDV; Sayers et al., 2015), Neospora caninum, Salmonella species (O'Doherty et al., 2013), Ostertagia ostertagi, Dictyocaulus viviparus (Bloemhoff et al., 2015a), and Fasciola hepatica (Bloemhoff et al., 2015b).

Data relating to on-farm vaccination and biosecurity (bioexclusion and biocontainment) protocols were collected by questionnaire from each participating farmer. Based on this self-reported information, herds were classified as BoHV-1 vaccinated (V) or unvaccinated (UV) and as open (introduced animals frequently or occasionally to the herd) or closed (never introduced new animals to the herd) herds. Biocontainment parameters recorded were related to cleaning of calving and calf pens, ownership of basic veterinary equipment, isolation of sick animals, and use of footbaths. A complete set of test results and vaccination data were not available for 7 herds and production data were therefore sought for 305 herds for inclusion in the analysis.

\section{Production Data}

Production data for each study herd were obtained from the ICBF database. Individual milk recording test day records of milk, fat, and protein yields were downloaded from the ICBF database. Predicted daily yields from ASReml-fitted splines (Gilmour et al., 2009) were used to estimate milk yields per cow per day on bulk milk sample collection dates (longitudinal individual cow data for mixed-effects models). Additionally, these data were used to calculate individual cow 305-d milk, fat, and protein yields from which herd averages were calculated [herd-level data for fixed effect linear regression (OLS) models]. Herd-level geometric mean SCC was also calculated from individual ICBF cow records. Data were collated separately for primiparous $(\mathbf{P p})$ and multiparous ( $\mathbf{M p}$ ) cows.

To examine herd fertility performance, relevant data from 2009 and 2010 breeding and calving seasons were downloaded from the ICBF database. Inclusion of 2 years of data was necessary because calving data from 2010 were used as an indicator of the success of the 2009 breeding season. Parameters available included herd 3-wk, 6-wk, and 9-wk calving rates (calculated from individual calving records) and herd calving spread [number of days between start (date when 5 consecutive calves were born within a 7 -d period) and end (last calving event) of calving period]. Similar to milk production parameters, calving rates and spread were calculated for Pp and Mp animals separately. Herd calving interval, percentage calves per cow per year, replacement rate, percentage cows not in calf, culling rate, and percentage of carryover cows was determined for the herd as a whole, regardless of parity. Submission rates, conception rates, and length of breeding season were not available for almost half of study herds and these variables were, therefore, not included in the analysis.

Neonatal (0-28 d old at death), youngstock ( $29 \mathrm{~d}-12$ mo at death), and adult ( $>12$ mo at death) mortality was examined and the number of cases of each calculated. Additionally, the number of deaths among youngstock (dead aged $>28 \leq 180 \mathrm{~d}$; dead aged $>180 \leq$ $270 \mathrm{~d}$; dead aged $>270 \leq 365 \mathrm{~d}$ ) and adult (dead aged $>1<2$ yr; dead aged $>2$ yr) sub-categories was also calculated. Data relating to the abortion rate on farms were not available.

The number of lactating animals (herd size), the parity of lactating animals, herd economic breeding index (EBI, €; a single figure profit index that comprises 7 sub-indices related to profitable milk production in Ireland; Veerkamp et al., 2002; Berry et al., 2007), median calving date, and proportion of Holstein-Friesian cows in each herd in 2009 was also downloaded from the ICBF for inclusion in regression models

\section{Descriptive Analysis}

Summary statistics were generated in Stata version 12 (StataCorp, College Station, TX). Means, standard errors, and ranges were calculated for all normally distributed parameters. Graphical representations of production parameters across bulk milk seropositive and seronegative herds were plotted in Excel (Microsoft Office 2010, Microsoft Corp., Redmond, WA).

\section{Statistical Analysis}

All statistical analyses were performed using Stata version 12 (StataCorp). Continuous data were visually checked for normality using ladders of power histograms to choose the most appropriate models for analysis. The mean and variance of nonnormally distributed dependent variables were calculated. Where the variance exceeded the mean, negative binomial (NBREG) models were applied. Ordinary fixed-effect linear regression was used for normally distributed parameters at the herd level and multi-level mixed effects models used at the level of individual cow.

Potential confounding variables were selected a priori from parallel studies and questionnaire data supplied by study farmers. These included bulk milk antibody status for BVDV, N. caninum, Salmonella, O. ostertagi, $D$. viviparous, and $F$. hepatica, and bioexclusion and 
biocontainment variables, which were used as surrogate confounders for general farm management. Chi-squared analysis was used to examine associations between BoHV-1 bulk milk antibody status and that of other diseases. Subsequently, the association between each dependent variable (herd performance variables), each independent variable (categorical or continuous BoHV1 results), and potential disease-related confounders was examined using OLS or NBREG, as appropriate. If a potential disease-related confounder recorded a significant association ( $P$-value of $\leq 0.15$ for this purpose) with both dependent and independent variables, it was included in the final regression model. Finally, surrogate confounders were included in all final models.

Both univariable and multivariable analyses were completed on fertility- and mortality-related parameters. Due to the considerable effect that independent variables (e.g., calving date, proportion of the herd that was Holstein-Friesian) would have on milk-related parameters, a multivariable analysis alone was completed. Two data sets were constructed, one (data set 1) that included all herds regardless of vaccination status, and a second (data set 2) where only UV herds were included. Data set 1 was used in models where categorical bulk milk serostatus (positive vs. negative) was the independent variable examined. Data set 2 was used to examine the association between ultrapurified IBR lysate ELISA readings and production parameters.

Covariates included in all multivariable OLS and NBREG models included herd size, proportion of Holstein-Friesian cows in the herd, median calving date, and herd EBI value in 2009 (EBI-2009). Average herd parity was only included in models where whole-herd analyses were conducted and was excluded as a covariate from Pp-specific analyses. Average cow parity (Mp cows only) was included in Mp analyses. Second- and third-level interactions between independent variables were investigated in all models and retained if the interaction term recorded a $P$-value $\leq 0.05$.

Variables were considered significant at $P<0.05$ with tendencies reported at $P \geq 0.05 \leq 0.15$.

\section{RESULTS AND DISCUSSION}

A complete set of BoHV-1 prevalence and vaccination data were available for 305 herds, $12 \%$ ( $\mathrm{n}=$ $36)$ of which were vaccinated, and $80 \%(\mathrm{n}=244)$ of which recorded bulk milk positive results (Sayers et al., 2015). Chi-squared analysis of BoHV-1 status and additional disease status is included in Supplementary Table S1 (https://doi.org/10.3168/jds.2016-11113) and highlights that associations existed between BoHV-1 status and $F$. hepatica $(P=0.035)$ and $N$. caninum $(P$ $=0.106)$ bulk milk antibody status, although results were not consistent when BoHV-1 vaccination status was accounted for. The likelihood of operating an open or closed herd did not differ across herds of differing BoHV-1 status $(P=0.386)$. In general, biocontainment measures also did not vary across BoHV-1 bulk milk status (Supplementary Table S2; https://doi. org/10.3168/jds.2016-11113), with the exception of owning basic veterinary equipment $(P=0.019)$.

Mean BoHV-1 ELISA sample/positive (S/P\%) values for UV herds in March, June, August and November were 144.76 (SD 83.51; range 0.16 to 408.76), 169.23 (SD 118.18; range 0 to 347.10), 160.35 (SD 111.21; range 0 to 306.73), and 198.79 (SD 145.11; range 0 to 450.62), respectively. Herd bulk milk serostatus has been previously shown not to significantly change over a lactation (Sayers et al., 2015). A single $\mathrm{V}$ herd recorded a negative result, the remaining 35 $\mathrm{V}$ herds yielding mean sample/negative $(\mathbf{S} / \mathbf{N})$ values of 0.34, 0.26, 0.36, and 0.35 in March, June, August, and November, respectively. A complete set of data for 287 herds (231 BoHV-1 bulk milk seropositive vs. 56 BoHV-1 bulk milk seronegative) was available for milkrelated dependent variables, data for $17 \mathrm{UV}$ and $1 \mathrm{~V}$ herd being unavailable. In the case of mortality and fertility parameters, 274 herds (217 BoHV-1 bulk milk seropositive vs. 57 BoHV-1 bulk milk seronegative) recorded a complete set of data (data set 1). Data were unavailable for 27 and $4 \mathrm{UV}$ and $\mathrm{V}$ herds, respectively. On exclusion of $\mathrm{V}$ herds (data set 2), 197 positive and 55 negative were available for milk analysis, with 56 negative and 186 positive herds available for mortality analysis.

Mean study herd size in 2009 was 99 cows (SD 86; range 28 to 445$)$ and the mean proportion of HolsteinFriesian cows across herds was 0.87 (SD 0.11; range 0.27 to 1.00). Herd EBI in 2009 ranged from $-€ 16$ to $€ 120$, the mean EBI being just over $€ 75$. Average herd parity in 2009 was 3.99 (SD 0.45; range 2.00 to 5.31). A summary of herd, Mp, and Pp milk performance across vaccination status is shown in Table 2 , with predicted individual cow daily milk yields for approximately 18,000 animals at each bulk milk sampling time point outlined in Table 3. Because of the predominance of spring-calving systems in Ireland (Dillon et al., 2008), an expected decrease in predicted milk, protein, and fat yields on bulk milk sampling dates was observed as the year progressed (Figure 1). The mean milk and milk solids yields across BoHV-1 bulk milk antibody positive and negative herds are outlined in Figure 2.

The mean number of calves born per study herd was 101 (range 32 to 405). The $2010 \mathrm{Mp}$ mean 3-, 6-, and 9 -wk calving rates were $38.79,61.29$, and $76.99 \%$, respectively, and give an indication of the success of the breeding season in 2009. Superior fertility performance 
Table 2. Study herd mean (SD) [range] annual milk and milk solids yield per cow across parity (multiparous, Mp; primiparous, Pp) and vaccination status

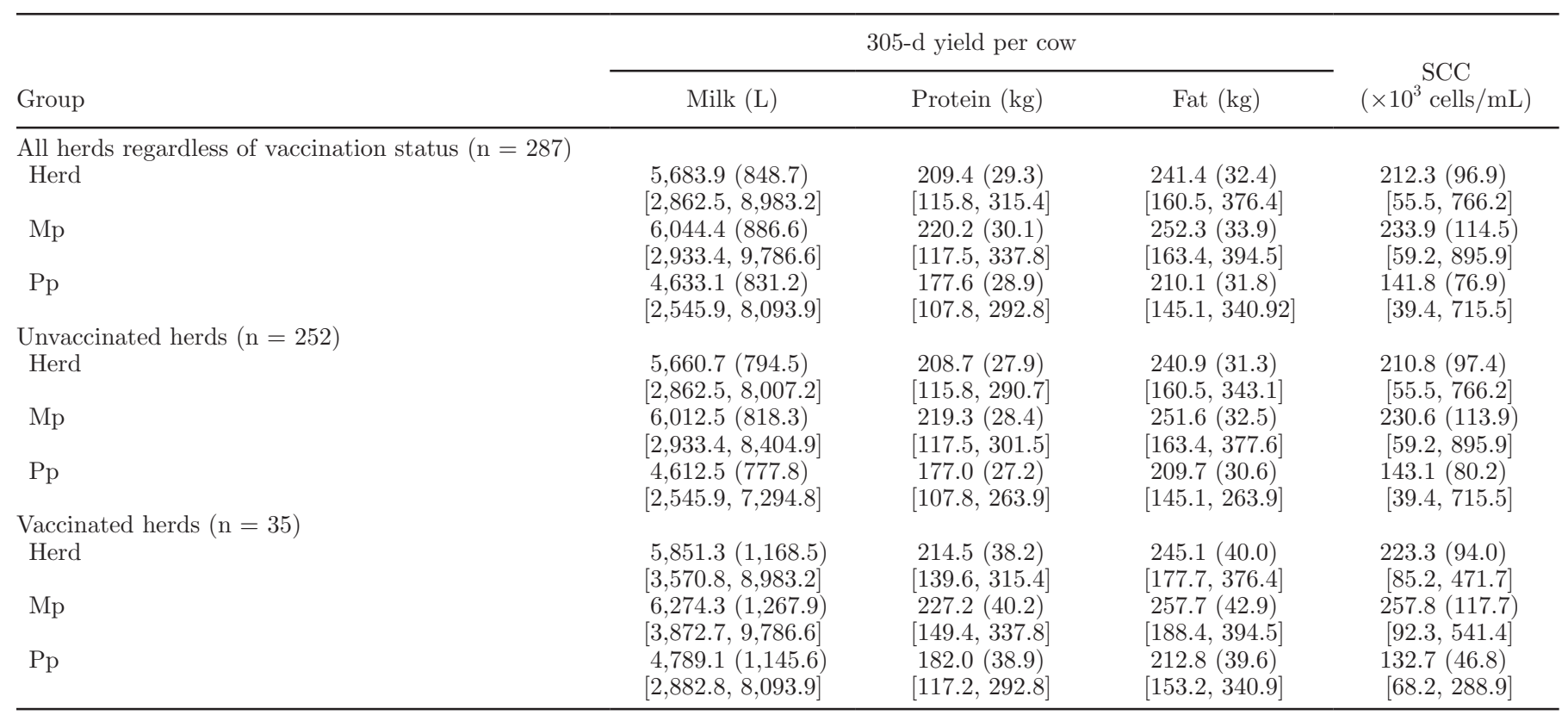

was observed in Pp animals, recording mean 3-, 6-, and 9 -wk calving rates of $50.19,76.33$, and $89.63 \%$, respectively. Cow calving spread in 2010 was 111 and $80 \mathrm{~d}$ for $\mathrm{Mp}$ and Pp animals, respectively. The mean proportion of cows not calved across study herds was almost $9 \%$. Of the 274 herds with recorded mortality data, the mean number of deaths per farm was approximately 13. The mean mortality rate among neonatal calves $(0$ to $28 \mathrm{~d}$ of age) and youngstock ( 28 to $365 \mathrm{~d}$ ) as a percentage of calves born was 5.19 and $3.39 \%$, respectively. The mean mortality rate among adult stock ( $>1$ yr old) was $3.25 \%$.

\section{Univariable and Multivariable OLS and NBREG Models}

Classification of performance-related dependent variables into normal and nonnormally distributed categories is included Supplementary Table S3 (https://doi. org/10.3168/jds.2016-11113), as is the regression model applied for each variable. The variance of all nonnormally distributed variables was greater than the mean, and NBREG models were therefore applied in all cases with the exception of SCC, which was log-transformed and analyzed using OLS regression. Examination of interaction terms between independent variables did not highlight any significant interaction terms for inclusion in final models.

The results of univariable NBREG analyses for fertility and mortality parameters are outlined in Table 4. Calving rates for Mp cows in 2010 were all significantly lower in BoHV-1 positive herds than in negative herds (decreasing by a factor of approximately 0.94), although this effect was not maintained in multivariable models. Of more significance was the increased proportion, by a factor of almost 1.4, of carryover cows in 2009 in the categorical multivariable model (Table 5). The proportion of cows not calved in 2010 was also increased by a factor of 1.001 for every unit increase in BoHV-1 ELISA S/P\% value in the multivariable BoHV-1 con-

Table 3. Predicted mean daily milk, protein, and fat yields per cow per day based on individual milk recording data

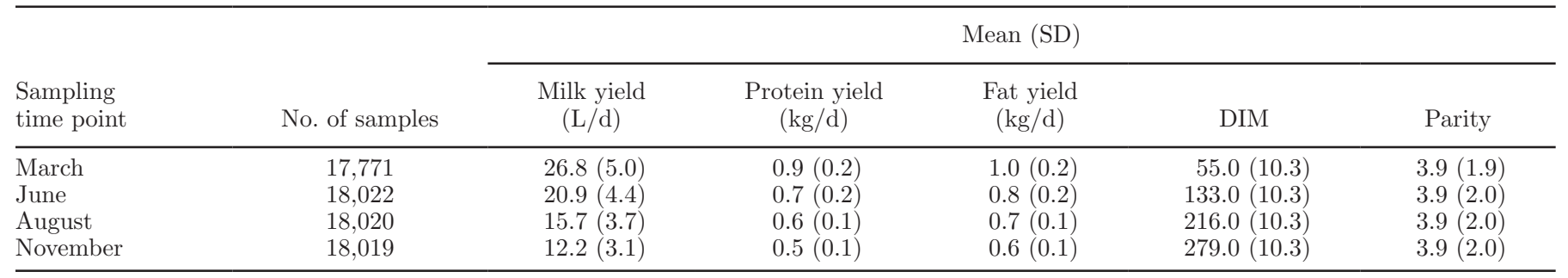


tinuous variable model. Median calving date and herd EBI in 2009 were significant in these models with an increase in median calving date associated with inferior fertility (incidence rate ratio; $\mathbf{I R R} \cong 1.01$ ) and an increase in EBI associated with superior fertility (IRR $\cong$ 0.98). Analysis of mortality counts across different age groups (calves, youngstock, adults) yielded relatively little in terms of an association with BoHV-1 bulk milk antibody status. Whole-herd mortality counts, however, were increased by a factor of 1.001 for every unit increase in BoHV-1 ELISA S/P\% value $(P=0.023)$ (Table 5).
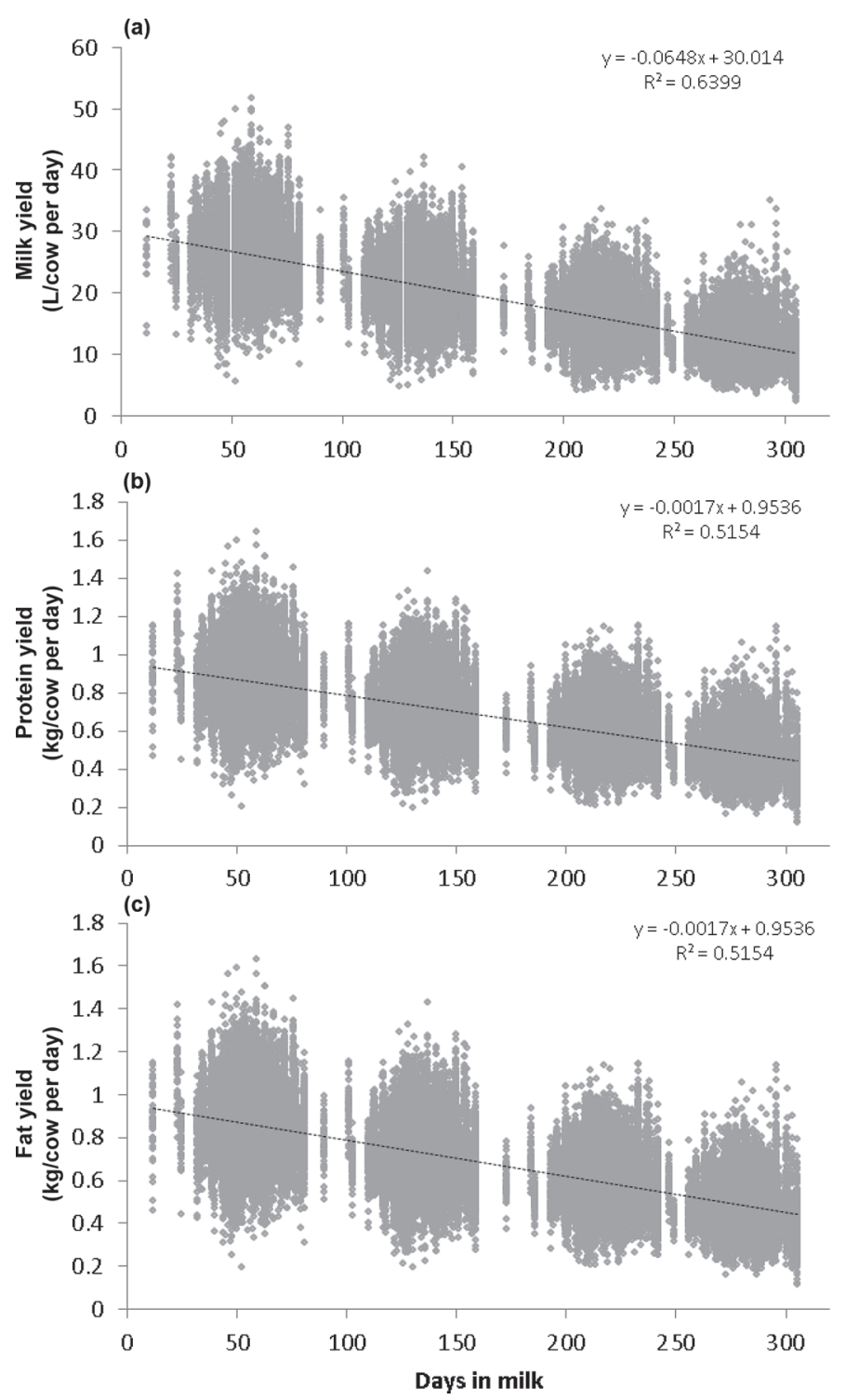

Figure 1. Scatterplot of predicted (a) milk, (b) protein, and (c) fat yields per cow versus number of days in milk at each bulk milk sampling time point (March, June, August, November).
A 250-L reduction in milk yield per $\mathrm{Mp}$ cow per year was identified in BoHV-1 positive herds compared with BoHV-1 negative herds $(P=0.042$; Tables 6 and 7$)$. Analysis of continuous data highlighted a comparable association in Mp cows in herds with increasing bulk milk antibody titers (Table 6). Milk fat and milk protein yield was reduced by almost $11 \mathrm{~kg} /$ cow per year $(P=0.033)$, and $8 \mathrm{~kg} /$ cow per year $(P=0.062)$, respectively. An effect on milk yield was also recorded in herds positive for F. hepatica and $N$. caninum, recording a decrease of just over $171 \mathrm{~L}$ per Mp cow per year and an increase of almost $100 \mathrm{~L}$ per Mp cow per year, respectively. No effect on Mp SCC was detected although a $12.9 \%$ increase in $\mathrm{SCC}$ was recorded in Pp cows in positive herds $(P=0.055)$ compared with bulk milk negative herds.

Estimates for all variables included in Mp milk and milk solids yield models are included in Table 7. An increasing proportion of Holstein-Friesian cows led to a significantly increased milk and milk solids yield $(P$ $<0.001)$, and an increase in mean EBI of $€ 1$ led to a milk yield loss of almost $8 \mathrm{~L}$ per cow per year $(P$ $=0.004)$. Reductions in milk fat and milk protein, however, were not associated with EBI. Interestingly, a tendency was highlighted for improved milk production parameters in closed compared with open herds (Table 6). Although significant associations were not identified for additional explanatory variables in milk-related models, $\mathrm{R}^{2}$ values increased on their inclusion, and they were therefore retained in final models.

Dairy farmers and their service providers benefit from access to data that allow identification and prioritization of areas within their production system that require improvement (Enevoldsen et al., 1996). Examining the associations between herd disease status and performance parameters such as milk production, fertility, and mortality, therefore, is of value. In the present study, I aimed to highlight associations between BoHV-1 herd exposure and herd performance in a geographically representative group (O'Doherty et al., 2013) of Irish dairy herds. Herd exposure to BoHV-1, as evidenced by a positive bulk milk ELISA reading, was found to be associated with suboptimal milk production in particular, highlighting a potential economic opportunity for the implementation of effective BoHV1 control.

Completion of disease cost-benefit analysis requires a measure of disease prevalence within the population of interest, whether that is at a herd, regional, or national level. National data are particularly useful in achieving farmer "buy-in" to national control or eradication programs, but national prevalence studies are often prohibitively expensive (Thrushfield, 2005). Bulk milk testing overcomes this issue somewhat, and reliable 

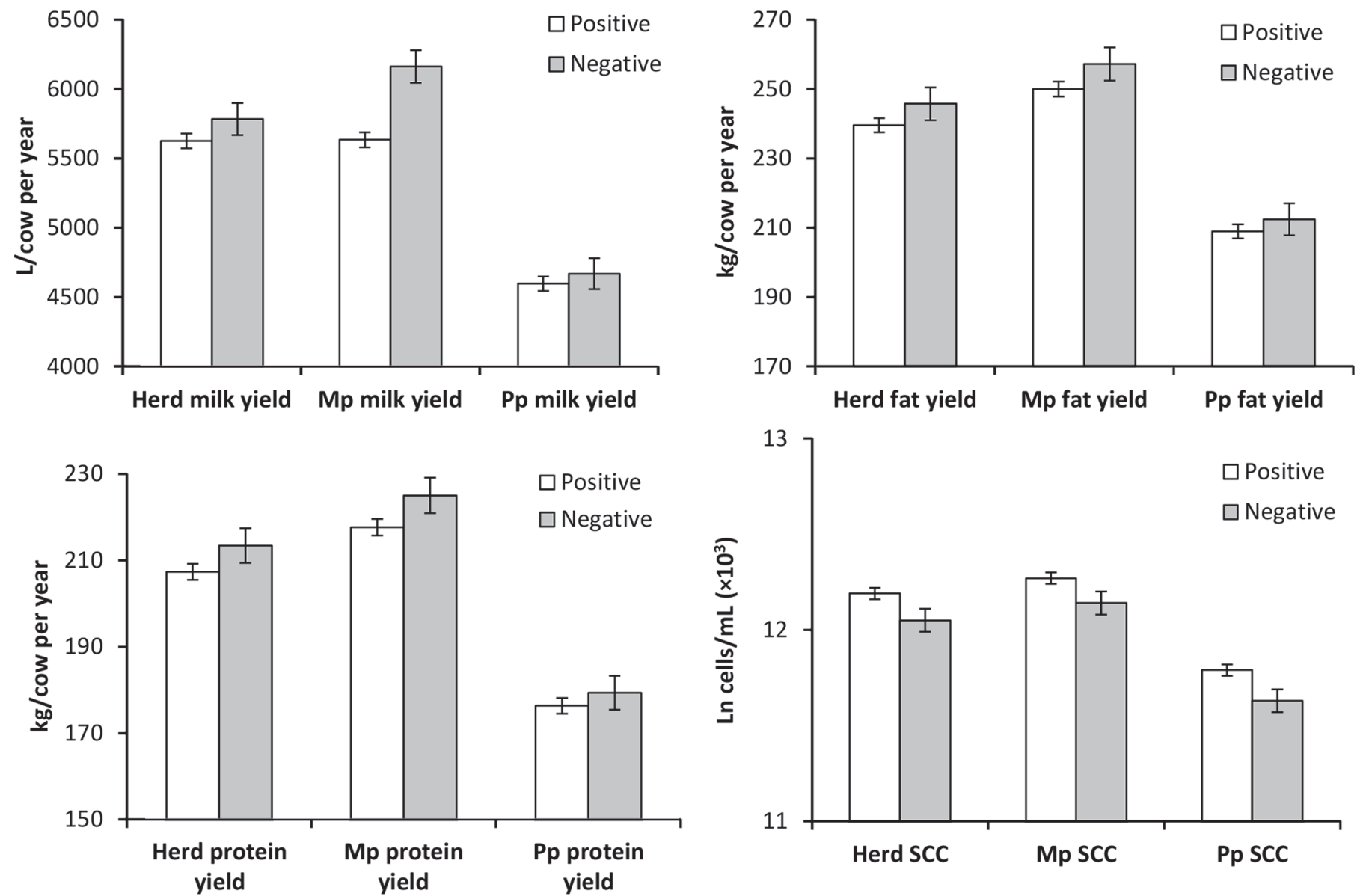

Figure 2. Differences in mean milk, fat, and protein yields, and SCC between bovine herpesvirus 1 (BoHV-1) bulk milk-positive and bulk milk-negative herds. Data are presented for herd, multiparous (Mp), and primiparous (Pp) cows. Error bars represent SEM of each parameter examined.

Table 4. Univariable negative binomial regression analysis of herd mortality and fertility-related parameters across bovine herpesvirus 1 (BoHV1) herd status

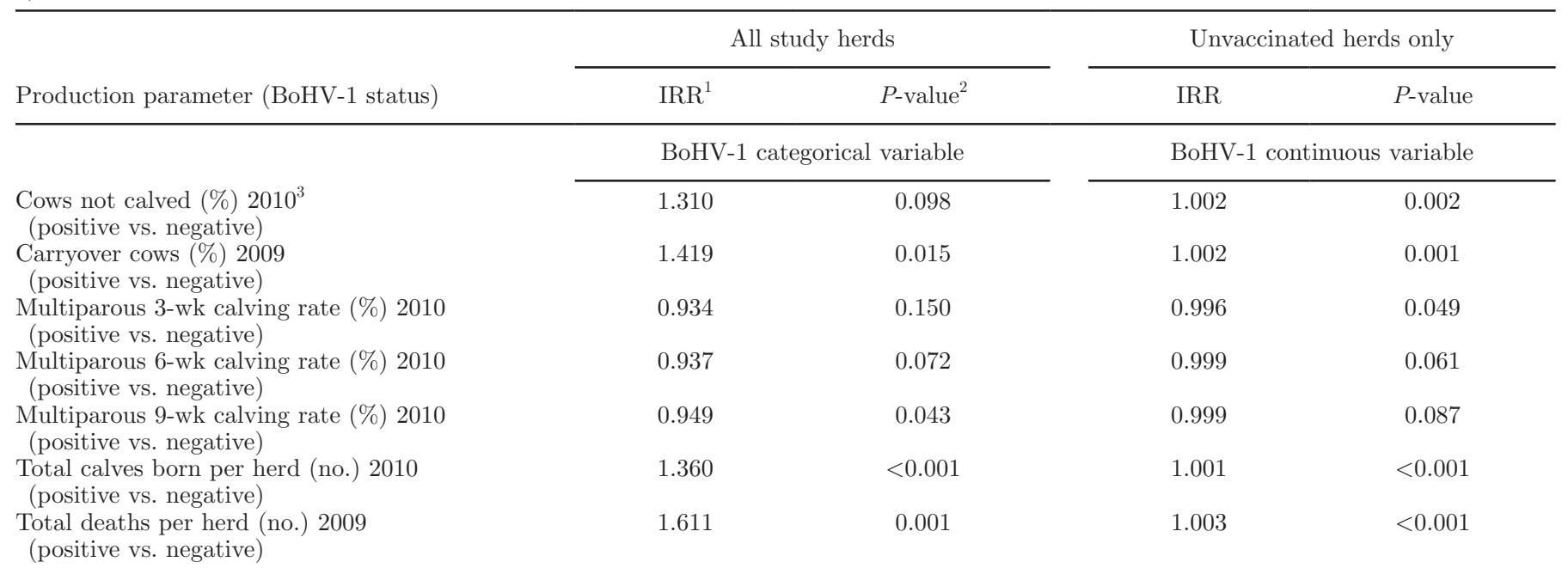

${ }^{1} \mathrm{IRR}=$ incidence rate ratio.

${ }^{2}$ Parameters with $P$-values $\leq 0.15$ are reported.

${ }^{3}$ The 2010 parameters are used as an indication of the success of the 2009 breeding season. 
Table 5. Multivariable negative binomial regression analysis of significant herd fertility and mortality performance parameters across bovine herpesvirus 1 (BoHV-1) herd status and ELISA readings

\begin{tabular}{|c|c|c|c|c|}
\hline $\begin{array}{l}\text { Production parameter } \\
\text { and variables compared }\end{array}$ & $\begin{array}{l}\text { Additional significant variables } \\
\text { in each model }\end{array}$ & $\operatorname{IRR}^{1}$ & $95 \% \mathrm{CI}$ & $P$-value ${ }^{2}$ \\
\hline \multicolumn{5}{|l|}{ Herd status as categorical variable } \\
\hline \multirow{2}{*}{$\begin{array}{l}\text { Carryover cows (\%) } 2009 \\
\text { (positive vs. negative) }\end{array}$} & Median calving date & 1.011 & $1.004,1.019$ & 0.004 \\
\hline & EBI- $2009^{3}$ & 0.979 & $0.973,0.986$ & $<0.001$ \\
\hline \multicolumn{5}{|l|}{ BoHV-1 ELISA as continuous variable } \\
\hline Carryover cows (\%) 2009 & EBI-2009 & 0.980 & $0.974,0.987$ & $<0.001$ \\
\hline \multirow[t]{3}{*}{ Cows not calved (\%) $2010^{4}$} & & 1.001 & $1.000,1.003$ & 0.047 \\
\hline & Median calving date & 1.019 & $1.009,1.029$ & $<0.001$ \\
\hline & EBI-2009 & 0.993 & $0.985,1.001$ & 0.074 \\
\hline \multirow[t]{2}{*}{ Total deaths per herd (no.) 2009} & & 1.001 & $1.000,1.002$ & 0.023 \\
\hline & Herd size & 1.008 & $1.006,1.011$ & $<0.001$ \\
\hline
\end{tabular}

${ }^{1} \mathrm{IRR}=$ incidence rate ratio

${ }^{2}$ Only parameters with $P$-values $\leq 0.15$ are reported

${ }^{3}$ Herd economic breeding index in 2009.

${ }^{4}$ The 2010 parameters are used as an indication of the success of the 2009 breeding season.

antibody detection bulk milk test procedures have been developed for both BoHV-1 vaccinated and unvaccinated herds (Nylin et al., 1999; Kramps et al., 2004). Furthermore, there has been a legal requirement for all BoHV-1 vaccines administered in Ireland to be marker or DIVA (Differentiating Infected from Vaccinated Animals) vaccines to allow differentiation between infected and vaccinated individuals (van Oirschot, 1999) since December 31, 2004, which further facilitates the use of bulk milk testing in Ireland.

The disadvantage of bulk milk analysis, however, is that data relate to the lactating herd only, the disease status of which may differ from that of younger livestock in the herd. This is particularly true of BoHV-1, where youngstock often remain seronegative (after maternally derived antibodies have dissipated) until over 2 yr of age (Van Wuijckhuise et al., 1998; Solis-Calderon et al., 2003). It is perhaps not surprising, therefore, that mortality rates of different age groups in study herds did not differ between BoHV-1 bulk milk antibody positive and negative herds. Although it is very possible that endemic BoHV-1 does not affect mortality rates in infected herds, it is also likely that my study design is not optimal for identifying such a trend.

Table 6. Multivariable linear regression analysis of herd, multiparous $(\mathrm{Mp})$ and primiparous $(\mathrm{Pp})$ animal performance parameters across bovine herpesvirus 1 (BoHV-1) herd status and ELISA readings

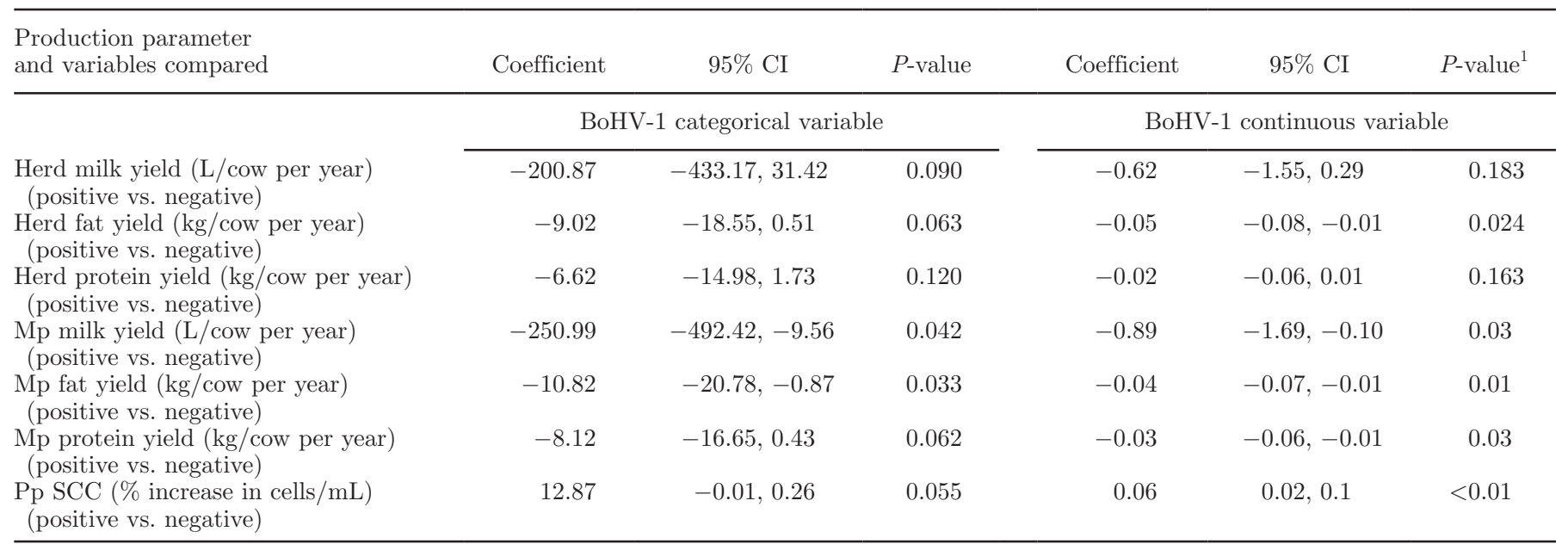

${ }^{1}$ Parameters with $P$-values $<0.20$ are reported. 


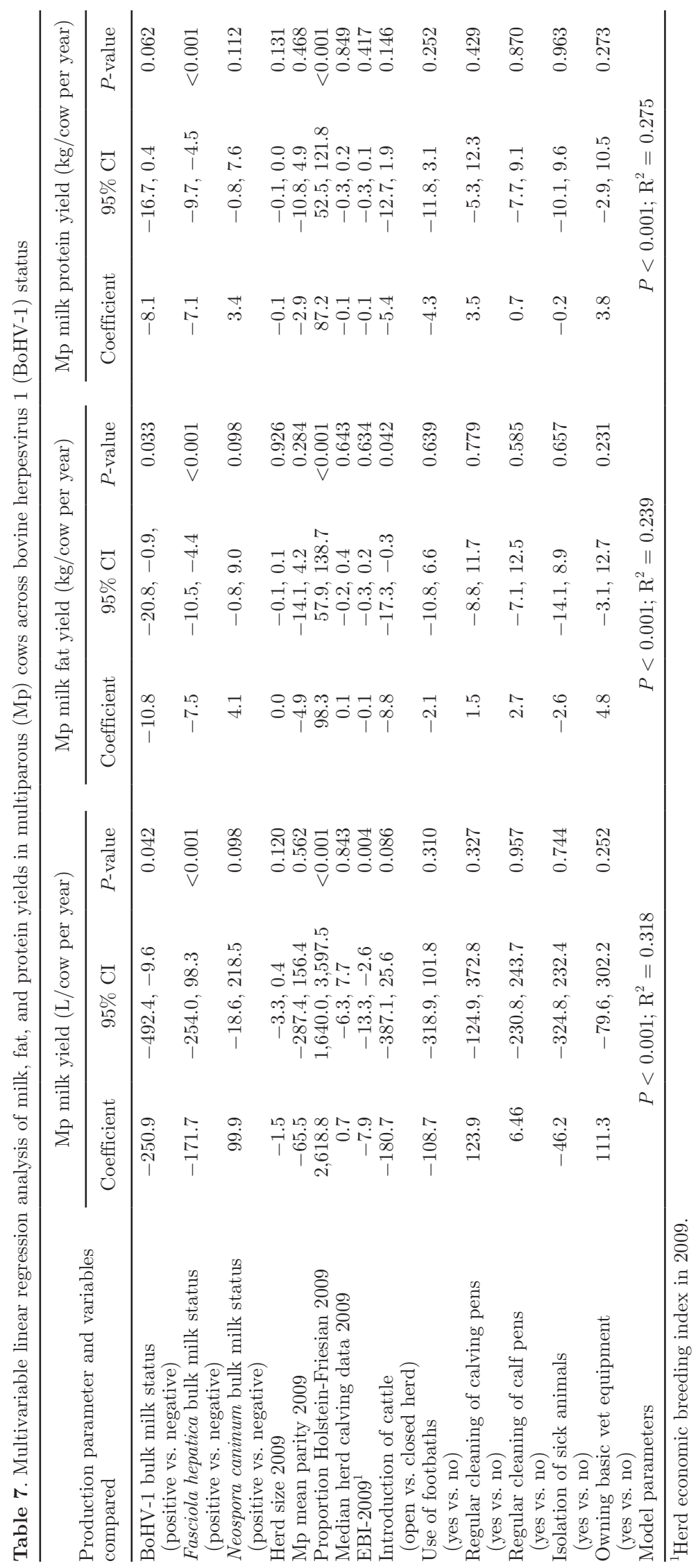


An additional disadvantage of using a bulk milk sample is the lack of discriminatory power at the level of the individual cow. This does highlight a weakness of my regression analysis, in that bulk milk seropositive herds will contain both seropositive and seronegative individuals. Bulk milk samples for many diseases usually test to a specified within-herd prevalence; that is, a minimum number of seropositive cows will have to contribute to the sample for a positive result to be recorded (Sekiya et al., 2013), which can lead to misclassification of herds. Nekouei et al. (2015) have shown that the possibility of herd misclassification using bulk milks can be reduced by testing multiple samples over a lactation. As my herd classification was based on the use of 4 bulk milk samples from each herd, the possibility of herd misclassification should be reduced considerably. To overcome any issue in this regard, however, herd-level analyses were conducted on both categorical and continuous bulk milk ELISA data. In general, comparable results were obtained across multivariable categorical and continuous models and use of actual ELISA results avoids the requirement for herd classification as positive or negative based on a manufacturer recommended positive cut-off value. The use of a continuous independent variable may prove a more useful approach, therefore, should the potential for herd misclassification exist.

Bulk milk testing is an economical and commonly used method of determining herd disease status. Many farmers now routinely test bulk milk samples for various infectious diseases (Sekiya et al., 2013). Use of bulk milk data allowed completion of a national study of over 250 herds representing a cow population of approximately 25,000 cows. These data can now be used to allow determination of the cost-benefit of applying control strategies, an essential step in examining the likely financial return from application of national disease eradication programs (Stott et al., 2012).

Data from herds endemically infected with a disease are more useful in convincing farmers to undertake control measures, because such data are often more reflective of their herd's disease status (Stott et al., 2010). Much of the BoHV-1 performance data presented in the literature relate to disease outbreaks, which are often assumed to inflict greater losses on a herd. Although this may be the case in the short term, continuous losses from endemic infections can be substantial in the longer term. Gunn et al. (2004) have demonstrated how BVDV-antibody positive herds can record substantial ongoing losses due to the presence of susceptible animals in a seropositive herd. It is likely that BoHV-1 could result in similar ongoing losses due to the dynamics of BoHV-1 spread within a herd and intermittent reactivation of latent infections in unvac- cinated carrier animals (Muylkens et al., 2007). Indeed, Statham et al. (2015) documented such losses over a 2-yr longitudinal study in the United Kingdom at the individual cow level in a single herd. The subclinical milk losses recorded in our study herds were lower than that recorded by Statham et al. (2015). This is most likely due to the lower milk yields of Irish dairy cows (Dillon et al., 2008), leading to losses in milk production being proportionally smaller. Additionally, the UK study was conducted on a single herd, at the individual cow level, which could also account for the differences recorded.

As well as an overall herd analysis, investigations of $\mathrm{Pp}$ and Mp cows were completed to reflect the usual age profile of BoHV-1 in herds, a higher proportion of older animals within herds being seropositive (Jacevičius et al., 2010; Raaperi et al., 2012b). This was a useful exercise because it highlighted the fact the $\mathrm{Pp}$ cows would not appear to be affected by BoHV-1 to the same degree as Mp cows. This is potentially due to BoHV-1 seroconversion in $\mathrm{Pp}$ cows occurring only at some point during their first lactation. This may account for the significant association between BoHV-1 herd status and SCC recorded in this sub-population, an association between BoHV-1 status and SCC having been previously reported (Rola et al., 2015). The typically lower milk yield of Pp cows (Dematawewa and Berger, 1998) may also have affected the ability to detect significant associations between BoHV-1 herd status and reductions in milk yield and solids.

Irish dairy farmers are paid for their produce based on milk solids rather than overall milk yield. The predominance of manufacturing milk (used to produce milk powder, butter, and additional milk derived products) produced in Ireland (Dillon et al., 2008) requires such a focus. The EBI in Ireland has, therefore, been used to reduce the focus on breeding cows for milk volume but instead concentrating on maintaining levels of milk solids. This is reflected in the multivariable results reported in the current study; herd EBI in 2009 was significantly associated $(P=0.004)$ with a reduction in milk yield, whereas no significant effect on milk solids was recorded, which supports the validity of the regression model used. Rola et al. (2015) have reported an association between milk fat yield and BoHV-1 status, and I suggest, based on the current results, that an effect on protein yields also occurs. It is important to investigate milk composition as well as milk yield in studies such as this, particularly in regions that focus on manufacture of milk-derived products for export. This will allow the full impact of endemic BoHV-1 infection in a herd to be quantified regardless of milk payment arrangements in particular regions and countries. 
A successful dairying operation will aim to achieve 1 calf per cow every $365 \mathrm{~d}$. Meeting this target is particularly important in pasture-based systems, such as in Ireland, because lactation must coincide with the grass growing season (i.e., March to October in the Northern Hemisphere). This necessitates a compact spring-calving season because cows calving later in springtime have shorter lactations thereby reducing farm profitability. Calving spread and calving rates therefore need to be optimal in pasture-based systems (Dillon et al., 1995; McCarthy et al., 2007). Infection with BoHV-1 can result in in early embryonic death and abortion (Anderson, 2007; Raaperi et al., 2012a), both of which have the potential to increase overall calving spread and decrease herd calving rates. Abortion can also lead to an increase in carryover cows, again adding to the inefficiency of a dairy production system (Patton, 2012). Various international studies have failed to document associations between BoHV-1 infection and poor reproductive performance (Hage et al., 1998; Pritchard et al., 2003; Waldner and Kennedy, 2008). The current study would appear to support this, although the percentage of carryover cows in 2009 may indicate an increased rate of embryonic loss or abortion in BoHV-1 bulk milk positive herds.

Raaperi et al. (2012a) showed that infection with BoHV-1 is a risk factor for a high incidence of abortions and a high insemination index in breeding animals and, although not maintained in multivariable models, significant associations between Mp fertility parameters and BoHV-1 herd status were identified in univariable models in the current study. It is interesting to note that univariable associations were stronger when the entire study population was used for analysis, rather than the smaller UV study population. It may be that detection of reduced fertility performance in BoHV-1 bulk milk positive herds using the current study design may have required a larger sample size, although an expected decrease $(\operatorname{IRR}=0.98)$ and increase $(\operatorname{IRR}=1.01)$ in the rate of carryover cows was highlighted for higher herd EBI and later median calving dates, respectively. The differences in outcomes across all previously published studies and this current study may reflect variances in study design (Raaperi et al., 2012a). Larger scale studies may be better placed to determine the fertilityrelated consequences, if any, due to endemic BoHV-1.

Bovine herpesvirus 1 is a major contributor to bovine respiratory disease complex, in conjunction with BVDV, parainfluenza 3 , and bovine respiratory syncytial virus. Bovine respiratory disease complex is a leading cause of morbidity and mortality, especially in feedlot systems (Van Drunen Little-van den Hurk, 2006). Bovine herpesvirus 1 can predispose cattle to secondary bacterial pneumonia (Narita et al., 2000; Leite et al., 2002; Nandi et al., 2009) and it was expected that mortality rates recorded in BoHV-1 positive herds would be increased. In general, this was not found to be the case, although the total number of deaths in study herds increased marginally. Given the high seroprevalence of BoHV-1, calves will receive protection via passive transfer from the dam, which will reduce the risk of a morbid episode (Mechor et al., 1987). As pooling colostrum is common in Ireland (Kennedy et al., 2014), it is unlikely that calves born even in moderately seropositive herds will be completely naïve in the early stages of life, which may assist in reducing calf mortality rates.

Identifying and correcting for confounding variables in observational studies always presents difficulties (Kamangar, 2012). It requires collection of data on potential confounders, and in cases where this is not possible, collection of data on surrogate confounders. The herds used for this analysis were part of a large bulk milk prevalence study conducted in Ireland in 2009. Data relating to several other infectious diseases, as well as herd management and biosecurity protocols were, therefore, available for analysis. These data allowed investigation of potential disease confounders, and use of bioexclusion and biocontainment measures employed on each farm as surrogate confounders to represent farm management. Model fit improved on inclusion of disease- and biosecurity-related variables and, to a large degree, estimates across potential confounders and covariates yielded logical outcomes. Higher herd EBI was significantly associated with improved milk solids yield, reduced milk yield, and a decreased rate of carryover cows. Later median calving dates were associated with an increased rate of carryover cows. An increased proportion of Holstein-Friesian cows was associated with higher milk yields, and closed herds also tended toward recording improved milk and milk solids yields. It may have been expected that median calving date would affect milk output. Given the spring-calving nature of Irish herds, however, it was not surprising that it had little effect. The logical nature of these findings supports the statistical methods applied in the current analysis and strengthens the findings presented.

The farmer population chosen for this study was the population of milk recording herds in Ireland recorded in the ICBF database. Not only did this provide access to the performance of each herd in terms of milk production, but these herds also record fertility and mortality data. With 3,500 herds recorded on the database in 2009, this sub-population represented $20 \%$ of the Irish national dairy herd. The use of stratified random selection based on geographical location and herd size assisted in selecting nationally representative groups of farmers. Although the final population of farmers recruited to the study were geographically representa- 
tive of the national dairy population, the mean herd size of the group was larger than the national average of 55 cows, which may have introduced a degree of bias (Teagasc, 2016). As dairy herd size in Ireland has been increasing steadily since 2009 (the national average herd size in 2015 was 76 cows; CSO, 2016)), the data generated in this study may be more representative of Irish dairy farms currently.

This study has examined the direct on-farm losses associated with the presence of BoHV-1 seropositive cows in a dairy herd. What has not been addressed nor quantified by any study, to the best of my knowledge, are the losses due to trade restrictions for exporting nations and genetic losses due to the unsuitability of BoHV-1 seropositive bulls for artificial insemination breeding programs in many jurisdictions. Such studies should be prioritized to provide further cost estimates in support of BoHV-1 control programs.

\section{CONCLUSIONS}

The current study highlights an economical method of investigating losses due to endemic infection using repeated bulk milk sampling over a single lactation. Reductions in milk-related performance, and minor effects on herd fertility and mortality were identified, adding to the growing evidence that subclinical BoHV1 can result in ongoing losses in dairy herds. These data can contribute to analyzing the cost-benefit of applying BoHV-1 control strategies.

\section{ACKNOWLEDGMENTS}

This research was funded by the Irish Dairy Levy. The author acknowledges assistance with data management from Donagh Berry and Eugene O'Doherty (Teagasc, Moorepark, Ireland). Additionally, the support of the Irish Cattle Breeding Federation and participating farmers in supplying performance data is gratefully acknowledged.

\section{REFERENCES}

Ackermann, M., and M. Engels. 2006. Pro and contra IBR-eradication. Vet. Microbiol. 113:293-302.

Anderson, M. L. 2007. Infectious causes of bovine abortion during mid- to late-gestation. Theriogenology 68:474-486.

Berry, D. P., L. Shalloo, A. R. Cromie, V. Olorib, R. F. Veerkamp, P. Dillon, P. R. Amer, R. D. Evans, J. F. Kearney, and B. Wickham. 2007. The economic breeding index: a generation on. Technical report to the Irish Cattle Breeding Federation. Accessed Jan. $25, \quad 2016$. http://www.icbf.com/publications/files/economic _ breeding index.pdf.

Bloemhoff, Y., A. Forbes, B. Good, E. Morgan, G. Mulcahy, M. Sekiya, and R. Sayers. 2015b. Determining the prevalence and seasonality of Fasciola hepatica in pasture-based dairy herds in Ireland using a bulk tank milk ELISA. Ir. Vet. J. 68:16.
Bloemhoff, Y., A. Forbes, B. Good, E. Morgan, G. Mulcahy, C. Strube, and R. Sayers. 2015a. Prevalence and seasonality of bulk milk antibodies against Dictyocaulus viviparus and Ostertagia ostertagi in Irish pasture-based dairy herds. Vet. Parasitol. 209:108-116.

Bowen, R. A., R. P. Elsden, and G. E. Seidel Jr.. 1985. Infection of early bovine embryos with bovine herpesvirus 1 . Am. J. Vet. Res. 46:1095-1097.

Central Statistics Office (CSO). 2016. Number of Livestock in June (000 Head) by Region, Type of Animal and Year. Accessed June 20, 2016. http://www.cso.ie/px/pxeirestat/Statire/SelectVarVal/ saveselections.asp

Chiang, B. C., P. C. Smith, K. E. Nusbaum, and D. A. Stringfellow. 1990. The effect of infectious bovine rhinotracheitis vaccine on reproductive efficiency in cattle vaccinated during oestrus. Theriogenology 33:1113-1120.

Delgado, C. L. 2003. Rising consumption of meat and milk in developing countries has created a new food revolution. J. Nutr. 133:3907S-3910S.

Dematawewa, C. M. B., and P. J. Berger. 1998. Genetic and phenotypic parameters for 305-day yield, fertility, and survival in Holsteins. J. Dairy Sci. 81:2700-2709.

Dillon, P., S. Crosse, G. Stakelum, and F. Flynn. 1995. The effect of calving date and stocking rate on the performance of spring calving dairy cows. Grass Forage Sci. 50:286-299.

Dillon, P., T. Hennessy, L. Shalloo, F. Thorne, and B. Horan. 2008. Future outlook for the Irish dairy industry: A study of international competitiveness, influence of international trade reform and requirement for change. Int. J. Dairy Technol. 61:16-29.

Drennan, M. J., A. F. Carson, and S. Crosse. 2005. Overview of animal production from pastures in Ireland. Pages 19-35 in Utilisation of Grazed Grass in Temperate Animal Systems. Proc. Satellite Workshop of the XXth International Grassland Congress, Cork, Ireland. Wageningen Academic Publishers, Wageningen, the Netherlands.

Enevoldsen, C., J. Hindhede, and T. Kristensen. 1996. Dairy herd management types assessed from indicators of health, reproduction, replacement and milk production. J. Dairy Sci. 79:1221-1236.

Engels, M., and M. Ackermann. 1996. Pathogenesis of ruminant herpesvirus infections. Vet. Microbiol. 53:3-15.

Geary, U., N. Lopez-Villalobos, D. J. Garrick, and L. Shalloo. 2010. Development and application of a processing model for the Irish dairy industry. J. Dairy Sci. 93:5091-5100.

Gilmour, A. R., B. J. Gogel, B. R. Cullis, and R. Thompson. 2009. ASReml User Guide Release 3.0. VSN International Ltd., Hemel Hempstead, HP1 1ES, UK.

Givens, M. D., and M. S. D. Marley. 2008. Infectious causes of embryonic and foetal mortality. Theriogenology 70:270-285.

Graham. D. A. 2013. Bovine herpes virus-1 (BoHV-1) in cattle-A review with emphasis on reproductive impacts and the emergence of infection in Ireland and the United Kingdom. Ir. Vet. J. 66:15.

Gunn, G. J., A. W. Stott, R. W. Humphry, and G. Jones. 2004. Modelling and costing BVD outbreaks in beef herds. Vet. J. 167:143-149.

Hage, J. J., Y. H. Schukken, T. H. Dijkstra, H. W. Barkema, P. H. R. van Valkengoed, and G. H. Wentink. 1998. Milk production and reproduction during a subclinical bovine herpesvirus 1 infection on a dairy farm. Prev. Vet. Med. 34:97-106.

Häsler, B., K. S. Howe, P. Presi, and K. D. C. Stärk. 2012. An economic model to evaluate the mitigation program for bovine viral diarrhea in Switzerland. Prev. Vet. Med. 106:162-173.

Jacevičius, E., A. Šalomskas, M. Milius, S. Petkevičius, I. Jacevičienè, G. Pridotkas, R. Mockeliūnas, A. Malakauskas, and M. Morkūnas. 2010. Five year serological study of bovine herpesvirus type-1 in cattle in Lithuania. Bull. Vet. Inst. Pulawy 54:289-292.

Kamangar, F. 2012. Confounding variables in epidemiological studies: basics and beyond. Arch. Iran Med. 15:507-516.

Kennedy, A. E. E. F. O'Doherty, N. Byrne, J. O'Mahony, E. M. Kennedy, and R. G. Sayers. 2014. A survey of management practices on Irish dairy farms with emphasis on risk factors for Johne's disease transmission. Ir. Vet. J. 67:27.

Kramps, J. A., M. Banks, M. Beer, P. Kerkhofs, M. Perrin, G. J. Wellenberg, and J. T. Van Oirschot. 2004. Evaluation of tests for 
antibodies against Bovine Herpesvirus 1 performed in national reference laboratories in Europe. Vet. Microbiol. 102:169-181.

Leite, F., M. J. Sylte, S. O'Brien, R. Schultz, S. Peek, K. van Reeth, and C. J. Czuprynski. 2002. Effect of experimental infection of cattle with bovine herpesvirus (BHV-1) on the ex vivo interaction of bovine leukocytes with Mannheimia (Pasteurella) haemolytica leukotoxin. Vet. Immunol. Immunopathol. 84:97-110.

McCarthy, S., B. Horan, P. Dillon, P. O'Connor, M. Rath, and L. Shalloo. 2007. Economic comparison of divergent strains of Holstein-Friesian cows in various pasture-based production systems. J. Dairy Sci. 90:1493-1505.

Mechor, G. D., C. G. Rousseaux, O. M. Radostits, L. A. Babiuk, and L. Petrie. 1987. Protection of newborn calves against fatal multisystemic infectious bovine rhinotracheitis by feeding colostrum from vaccinated cows. Can. J. Vet. Res. 51:452-459.

Miller, J. M., C. A. Whetstone, and M. J. Van der Maaten. 1991 Abortifacient property of bovine herpesvirus type 1 isolates that represent three subtypes determined by restriction endonuclease analysis of viral DNA. Am. J. Vet. Res. 52:458-461.

Moeller, R. B. Jr., J. Adaska, J. Reynolds, and P. C. Blanchard. 2013 Systemic bovine herpesvirus 1 infections in neonatal dairy calves. J. Vet. Diagn. Invest. 25:136-141.

Muylkens, B., J. Thiry, P. Kirten, F. Schynts, and E. Thiry. 2007. Bovine herpesvirus 1 infection and infectious bovine rhinotracheitis. Vet. Res. 38:181-209.

Nandi, S., M. Kumar, M. Manohar, and R. S. Chauhan. 2009. Bovine herpes virus infections in cattle. Anim. Health Res. Rev. 10:85-98.

Narita, M., K. Kimura, N. Tanimura, S. Arai, T. Tsuboi, and K. Katsuda. 2000. Immunohistochemical characterisation of calf pneumonia produced by the combined endobronchial administration of bovine herpesvirus 1 and Pasteurella haemolytica. J. Comp. Pathol. 123:126-134

Narrod, C., M. Tiongco, and R. Scott. 2011. Current and predicted trends in the production, consumption and trade of live animals and their products. Rev. Off. Int. Epizoot. 30:31-49.

Narrod, C., J. Zinsstag, and M. Tiongco. 2012. A One Health framework for estimating the economic costs of zoonotic diseases on society. EcoHealth 9:150-162.

Nekouei, O. H., J. Stryhn, D. VanLeeuwen, P. Kelton, G. Hanna, and G. Keefe. 2015. Predicting within-herd prevalence of infection with bovine leukemia virus using bulk-tank milk antibody levels. Prev. Vet. Med. 122:53-60.

Nylin, B. U., L. Strøger, and L. Rønsholt. 1999. A retrospective evaluation of a Bovine Herpesvirus-1 (BHV-1) antibody ELISA on bulktank milk samples for classification of the BHV-1 status of Danish dairy herds. Prev. Vet. Med. 47:91-105.

O'Doherty, E., R. Sayers, and L. O' Grady. 2013. Temporal trends in bulk milk antibodies to Salmonella, Neospora caninum, and Leptospira interrogans serovar hardjo in Irish dairy herds. Prev. Vet. Med. 109:343-348.

Patton, J. 2012. The economics of recycled cows and extended lactations. Accessed 24 Feb, 2016. http://www.teagasc.ie/ publications/2012/1581/index.asp.

Pritchard, G. C., M. Banks, and R. E. Vernon. 2003. Subclinical breakdown with infectious bovine rhinotracheitis virus infection in a dairy herd of high health status. Vet. Rec. 153:113-117.

Raaperi, K., A. Aleksejev, T. Orro, and A. Viltrop. 2012b. Dynamics of bovine herpesvirus type 1 infection in Estonian dairy herds with and without a control program. Vet. Rec. 171:99-105.

Raaperi, K., S. Bougeard, A. Aleksejev, T. Orro, and A. Viltrop. 2012a. Association of herd BRSV and BHV-1 seroprevalence with respiratory disease and reproductive performance in adult dairy cattle. Acta Vet. Scand. 54:4.
Rola, J. G. M., M. Larska, J. Grzeszuk, and J. Rola. 2015. Association between antibody status to bovine herpesvirus 1 and quality of milk in dairy herds in Poland. J. Dairy Sci. 98:781-789.

Sayers, R. G., N. Byrne, E. O'Doherty, and S. Arkins. 2015. Prevalence of exposure to bovine viral diarrhea virus (BVDV) and bovine herpesvirus-1 (BoHV-1) in Irish dairy herds. Res. Vet. Sci. 100:21-30

Sekiya, M., A. Zintl, and M. L. Doherty. 2013. Bulk milk ELISA and the diagnosis of parasite infections in dairy herds: a review. Ir. Vet. J. 66:14.

Solis-Calderon, J. J., V. M. Segura-Correa, J. C. Segura-Correa, and A. Alvarado-Islas. 2003. Seroprevalence of and risk factors for infectious bovine rhinotracheitis in beef cattle herds of Yucatan, Mexico. Prev. Vet. Med. 57:199-208.

Statham, J. M. E., L. V. Randall, and S. C. Archer. 2015. Reduction in daily milk yield associated with subclinical bovine herpesvirus 1 infection. Vet. Rec. 177:339.

Stott, A. W., R. W. Humphry, and G. J. Gunn. 2010. Modelling the effects of previous infection and re-infection on the costs of bovine viral diarrhea in beef herds. Vet. J. 185:138-143.

Stott, A. W., R. W. Humphry, G. J. Gunn, I. M. Higgins, T. Hennessey, J. O'Flaherty, and D. A. Graham. 2012. Predicted costs and benefits of eradication BVDv from Ireland. Ir. Vet. J. 65:12.

Teagasc. 2016. Dairy Industry Compendium. Chapter 2: Regional herd Statistics; Trends in milk production and herd size. Accessed Jun 20, 2016. http://www.teagasc.ie/dairy/statistics-links/ dairyindustrycomp.asp

Thrushfield, M. 2005. Veterinary Epidemiology. 3rd Edition. Blackwell Publishing Professional, Ames, Iowa, USA.

Vallat, B. 2008. Feeding the world better by controlling animal diseases. Accessed Sept. 25, 2016. http://www.oie.int/for-themedia/editorials/detail/article/feeding-the-world-better-bycontrolling-animal-diseases/.

van Drunen Little-van den Hurk, S. 2006. Rationale and perspectives on the success of vaccination against bovine herpesvirus-1. Vet. Microbiol. 113:275-282.

van Oirschot, J. T. 1999. Diva vaccines that reduce virus transmission. J. Biotechnol. 73:195-205.

van Schaik, G., M. Shoukri, W. Martin, Y. H. Schukken, M. Nielen, J. J. Hage, and A. A. Dijkhuizen. 1999. Modelling the effect of an outbreak of bovine herpesvirus type 1 on herd-level milk production of Dutch dairy farms. J. Dairy Sci. 82:944-952.

Van Wuijckhuise, L., J. C. Bosch, P. Franken, K. Frankena, and A. R. W. Elbers. 1998. Epidemiological characteristics of bovine herpesvirus 1 infections determined by bulk milk testing of all Dutch dairy farms. Vet. Rec. 142:181-184.

Veerkamp, R. F., P. Dillon, E. Kelly, A. R. Cromie, and A. F. Groen. 2002. Dairy cattle breeding objectives combining yield, survival and calving interval for pasture-based systems in Ireland under different milk quota scenarios. Livest. Prod. Sci. 76:137-151.

Waldner, C. L. 2005. Serological status for N. caninum, bovine viral diarrhea virus, and infectious bovine rhinotracheitis virus at pregnancy testing and reproductive performance in beef herds. Anim. Reprod. Sci. 90:219-242.

Waldner, C. L., and R. I. Kennedy. 2008. Associations between health and productivity in cow-calf beef herds and persistent infection with bovine viral diarrhea virus, antibodies against bovine viral diarrhea virus, or antibodies against infectious bovine rhinotracheitis virus in calves. Am. J. Vet. Res. 69:916-927.

Wellenberg, G. J., E. R. A. M. Verstratem, M. H. Mars, and J. T. van Oirschot. 1998. ELISA detection of antibodies to glycoprotein E of bovine herpesvirus 1 in bulk milk samples. Vet. Rec. 142:219-220. 